\title{
The international competitiveness research of china's agricultural products
}

\author{
Sun Chang \\ College of International Trade and Economics, Changchun University of Finance and Economics, Changchun 130000, China
}

\begin{abstract}
Since ancient times, China is a country with a large population and abundant agriculture. With the reform of China's market economy and entered WTO, it has improved the international participation degree of agricultural products in China. Especially in recent years, in the highly open international markets and countries have pledged to weaken their agricultural support, China's agricultural products in the international market ushered in a broader space for development, but due to various reasons, China's agricultural products trade has formed a huge deficit in recent years. To reduce the trade deficit, continue to expand exports of agricultural products, create income for China's foreign exchange and increase farmers' income, we need to continue improving the international competitiveness of China's agricultural products.
\end{abstract}

\section{The current situation of the international competitiveness of china's agricultural products}

\subsection{The scale of china's agricultural trade}

In recent years, with the efforts of the government and enterprises, the reform of agricultural industrialization in China has been accelerated, and the international trade of agricultural products has increased greatly. Agricultural products not only meet the domestic demand but also increase the intensity of exports, some high-quality agricultural products in the international market gradually increase market share and enhance competitiveness, In many export commodities of our country, these agricultural products gradually occupied a larger proportion of market share, at the same time, the emergence of a group of leading enterprises with a certain scale and strength, they form the brand and have a leading role in the export trade of agricultural products in China. It can also be seen from table 1, the total import and export trade of agricultural products in China in recent years continued growing steadily, but the proportion of total import and export trade has not followed the growth trend, on the basis of a small proportion originally, there is a reduction of the situation. In addition, in recent years, imports exceed exports and the trade deficit did not show a significant slowdown trend, the huge trade deficit is even normalized, floating more than $\$ 4$ billion.

\subsection{The current situation of China's agricultural products trade structure}

As can be seen from table 1, China's foreign import and export trade of agricultural products is concentrated in Asia, America and Europe. And over the years, the areas of China's import and export are Hongkong, Japan and South Korea, the United States and the European Union and other developed countries and regions. In 2014, the proportion of agricultural exports to Japan accounted for $15.6 \%$ of total exports, while exports to the United States, the European Union and Hongkong were 13.6\%, 14.5\% and $8.7 \%$ respectively. Consumer's income and living standards are similar, together with adjacent geographical position and low transportation cost, China's food export market mainly in Southeast Asia and other countries and regions around China. In the Middle East and Africa market, because of the geographical problem and expansive long-distance transportation costs and the living habits and diet culture, the proportion of China's grain exports is small relatively. This situation shows that on the one hand the development of China's agricultural products have greater market space, but on the other hand, the foreign trade market structure of China's agricultural products is single, it is vulnerable to suffer non-tariff barriers to trade sanctions on China's import and export of agricultural products, hinder the export of agricultural products. Because for the product exports, the wider distribution of goods in the world, the greater difficulty of the import of trade sanctions, the loss of trade sanctions will be less. China's foreign trade in agricultural products is too single or too much of one country's market share, once it suffered trade sanctions, losses will be great. So it is necessary to develop the international market of agricultural products deeply and improve the international competitiveness of agricultural products.

a Corresponding author: guotianbao1999@126.com 
Table 1. Total import and export changes of agricultural products in 2008 -2014 Unit: a hundred million dollars.

\begin{tabular}{|c|c|c|c|c|c|c|c|}
\hline \multirow{2}{*}{ Year } & \multirow{2}{*}{$\begin{array}{l}\text { Total imports } \\
\text { and exports }\end{array}$} & \multirow{2}{*}{ Exports } & \multirow{2}{*}{ Imports } & \multirow{2}{*}{$\begin{array}{l}\text { Trade } \\
\text { deficit }\end{array}$} & \multicolumn{3}{|c|}{ Increase and decrease over the previous year } \\
\hline & & & & & $\begin{array}{l}\text { Total imports } \\
\text { and exports }\end{array}$ & Exports & Imports \\
\hline 2014 & 3052.9 & 1295.0 & 1757.9 & 462.9 & $-5.44 \%$ & $-5.44 \%$ & $-5.49 \%$ \\
\hline 2013 & 3228.7 & 1368.9 & 1859.7 & -490.7 & $6.04 \%$ & $7.07 \%$ & $5.3 \%$ \\
\hline 2012 & 3044.7 & 1278.6 & 1766.1 & -487.5 & $10.22 \%$ & $3.64 \%$ & $15.54 \%$ \\
\hline 2011 & 2762.3 & 1233.7 & 1528.6 & -294.9 & $28.00 \%$ & $25.76 \%$ & $28.87 \%$ \\
\hline 2010 & 2158.1 & 981.0 & 1177.1 & -196.0 & $31.10 \%$ & $30.41 \%$ & $31.68 \%$ \\
\hline 2009 & 1646.1 & 752.2 & 893.9 & -141.6 & $-10.68 \%$ & $-8.67 \%$ & $-12.31 \%$ \\
\hline 2008 & 1843.0 & 823.7 & 1019.3 & -195.6 & $40.28 \%$ & $42.72 \%$ & $38.36 \%$ \\
\hline
\end{tabular}

Source: Ministry of Agriculture of the People's Republic of China.

Table 2. The summary of China's agricultural products import and export from different continent in 2014.

Unit: a hundred million dollars.

\begin{tabular}{|c|c|c|c|c|c|c|}
\hline & $\begin{array}{c}\text { Total imports and } \\
\text { exports }\end{array}$ & Proportion & Exports & Proportion & Imports & Proportion \\
\hline Total & 3228.63 & $100 \%$ & 1368.97 & $100 \%$ & 1859.65 & $100 \%$ \\
\hline Asia & 1300.17 & $40.27 \%$ & 763.40 & $55.76 \%$ & 536.77 & $28.86 \%$ \\
\hline Africa & 143.57 & $4,45 \%$ & 95.10 & $6,95 \%$ & 48.47 & $2.61 \%$ \\
\hline Europe & 497.08 & $15.40 \%$ & 228.99 & $16.73 \%$ & 268.09 & $14.42 \%$ \\
\hline Latin America & 616.15 & $19.80 \%$ & 166.57 & $12.17 \%$ & 449.58 & $24.17 \%$ \\
\hline North America & 466.56 & $14.45 \%$ & 87.16 & $6.37 \%$ & 379.40 & $20.40 \%$ \\
\hline Oceania & 205.09 & $6.35 \%$ & 27.75 & $2.03 \%$ & 177.34 & $9.54 \%$ \\
\hline
\end{tabular}

\section{The factors that affect the international competitiveness of china's agricultural products}

\subsection{The condition of production factors}

\subsubsection{The existing natural resources in China}

Land as the most basic factor of production has a very important influence on the development of agriculture. China's natural environment and natural resources of agricultural production have a good foundation: vast land area and fertile land, China's land and resources accounted for $11.1 \%$ of the Asia, accounted for $6.7 \%$ of the world, only second behind Canada. Our country holds the advantages of ecological conditions and natural environment zone, they are suitable for agricultural production. Subtropical zone, warm temperate zone and temperate area account for about $70 \%$ of the land area, suitable for large-scale agricultural production especially.
Then the huge population makes is much lower than the world average level, from this point of view, China's land resources are scarce. The actual situation of our country determines that although our country has about 1.3 hectares of arable land, but after average, it is only 0.1 hectares in per capita arable land, while the per capita arable land is 0.24 hectares, we only the $41.7 \%$ of world average, however, India also has the same large population, but it has 0.19 hectares. With the continuous increase of China's population, according to the predict of population and resources experts, China will reach the peak of the total population in future 20 years, which makes China's per capita arable land is shrinking, only 0.08 per hectare, let alone compared with the 73 hectares in United States. While in permanent grassland and pasture area, China's permanent grassland by the proportion of the world is as much as the Australian, and China's per capita permanent grassland is also higher than most European countries, but because of the low quality of our country's permanent grassland, it led to low yield, and the unit area and output are far less than the other countries, while Australia is the important exporter of beef and mutton in the world currently. And in fisheries, 
China's Ocean Fisheries in the world's total output of ocean fishing has no "status", not to mention compete the market share with other developed countries. And rich natural endowments are averaged by such a huge population, coupled with the blind predatory use of arable land resources, resulting in ecological degradation, are restricting the sustainable and stable development of China's rural economy and agricultural industry. Agricultural natural resources are the basis of improving the international competitiveness of agricultural products, only to pay more efforts to improve and strengthen the foundation, can we play a basic role in improving the international competitiveness of agricultural products. However, in order to protect the cultivated land and other natural resources, the international competitiveness of agricultural products in this no effect period of time is bound to be reduced.

\subsubsection{The backward conditions of infrastructure}

With the acceleration of the global integration process, the impact of agricultural modernization on the competitiveness of agricultural products has become more and more important. Facilities and equipment of agricultural production, communication, transportation facilities and other infrastructures through the production management, decision management, labor productivity, output level and utilization degree and efficiency of natural resources, indirectly affect the agricultural product quality, production cost, competition of service and price. China's existing water conservancy facilities are mostly built in the last century, functional aging, low efficiency, and some of them even disrepair. And other infrastructures are also unable to compare with the United States, Argentina and other major agricultural exports in the world, the backward infrastructure greatly restricted the development of China's rural economy and agricultural industry. Although the investment in agricultural infrastructure in rural areas is increasing in recent years, but it still needs a lot of effort to change the status quo.

\subsection{The demand situation of domestic and foreign market}

Since the reforming and opening up of China, China's consumption level has been continuously improved, and There have gradually changed in consumption structure and consumption consciousness. People's demand for variety and diversity of agricultural products is becoming more and more diversified, and more emphasis on the quality of agricultural products and nutritional value, people favor pollution-free agricultural products have increased, of which green food is a major representative. In order to adapt to such market demand, China's agricultural production enterprises will find ways to cater to the tastes of consumers, constantly innovate and develop new products, to ensure the quality of product and service on the basis of timely changes in marketing strategies to improve the competitiveness of agricultural products. However, the world's major exporting countries,
China's per capita consumption of grain ranked first, in addition to fish and eggs, the consumption of other products for the time being at a backward level. From the market structure, compared with other major exporting countries, China's consumption of most agricultural products is also dominated by primary product consumption, so the agricultural industry also stays in the production of primary products, the developed countries, the agricultural industry is more inclined to manufacturing. At the same time, compared with developed countries, Chinese consumer consumption for agricultural products, the criticality is still not enough, which reduces the pressure on the industry to enhance product quality.

\subsection{Business scale, strategic structure and competitors}

The scale of agricultural production affects the cost of agricultural products and the input of factors of production. China's agricultural production is mainly dominated by family management, the scale of agricultural production enterprises is generally small, the degree of organization of the industry is low, the utilization rate of agricultural science and technology is low, there is no large-scale agricultural mechanization, so the low degree of production efficiency lead to low quality and high production cost. The large-scale production of foreign countries are not only supported by large-scale agricultural machinery to do the formation of the situation of centralized marketing, circulation and processing also achieved the scale of operation, the scale of China's international competitiveness can not compete with foreign countries.

\subsection{Government}

Agriculture as the basic industry of the national economy, to provide surplus products and surplus labor for the secondary and tertiary industries. However, compared with other industries, agriculture may be subjected to natural risks in addition to market risks. This is also the reason why agriculture is different from other industries. Coupled with the difficulty of popularization of agricultural technology, agricultural production cycle is longer and so on, all countries attach great importance to the protection of agricultural industries. China's agricultural production, low degree of processing, low degree of organization, small scale, it can not be made timely to adjust the market when encountering changes in the market, low resistance to market impact, seriously constraining the development of China's agriculture. Therefore, the government must provide the policy guidance and macroeconomic regulation and control more powerful, giving more support to create a better market environment for the agricultural industry.

\section{The countermeasures to improve the international competitiveness of china 's agricultural products}




\subsection{Develop agricultural science and technology, improve productivity}

Science and technology are the primary productive force, then the agricultural science and technology are the primary productive force of agricultural development, to adjust and optimize the agricultural structure can not be separated from scientific and technological innovation and technology promotion. In recent years, China's international market competition has been regarded the low prices of product as the main competitive advantage, but due to the continuous development of the world economy, all-round put up in agricultural productivity, prices are not the main advantages of agricultural products, the quality-related competition has become more important. Therefore, in order to make China's agricultural products stand out in the international competition, to improve the quality of agricultural products has become inevitable, vigorously promote agricultural science and technology innovation is the fundamental way to improve the quality of agricultural products. The strengthening of scientific and technological innovation, it is necessary to strengthen the process of agricultural products, biotechnology that are the focus of new agricultural science and technology research, to improve the quality of agricultural products; but also to transform the newly research and development of technology achievements into real productive forces in a fastest speed, to achieve large-scale production, So to enhance the quality of agricultural products to achieve its improved, we should attach great importance to new technologies, vigorously popularize new technologies.

\subsection{Play the role of enterprises and markets}

\subsubsection{Cultivate the business entities, adjust the operating structure}

It is based on household contract responsibility system for China's agricultural production, individual farmers are small and scattered, farmers as producers also play a marketing role. Farmers' economic strength is limited, it is difficult to achieve the scale of processing of agricultural products, coupled with the lack of professional business knowledge, not timely get access to market information, so that agricultural products commercialization to meet the needs of the target market to gain more value-added benefits, But also China's famer obtain surplus with each other, low degree of organization. So we can find the fact that the lack of the individual operators that can combine the self-employed farmers. Integration of agricultural production and economic chain of the main business-oriented. The sensitivity of market signals for enterprise is much higher than that of individual farmers, and the source of market information is wide and fast. It also makes enterprises respond more prompter than farmers to market changes. The familiarity of business-to-market and the market development ability, coupled with large-scale operation and professional marketing, are the resources farmers can use. The formation of the main business is conducive to improving the overall level of China's agricultural industry and enhancing the international competitiveness of China's agricultural products.

\subsubsection{Optimize the industrial structure, open up new markets}

The improvement of living standard also strengthens the specificity of agricultural products, and the proportion of agricultural products is increasing. Because the structure of export market is single and the difference of export products is small, therefore, in order to make agricultural products gain Competitive advantage in the international market, it will require enterprises to optimize the industrial structure. According to the consumption level of consumer groups and the market demand for agricultural product quality, the market structure of agricultural products is divided into different regions and levels. It also need Enterprises continue to open up new export markets and new varieties of agricultural products market to obtain more market share, to win greater living space without being eliminated in an increasingly competitive international market, and corporate entities strengthen the rapid development of industry so that enhancing the competitiveness of China's agricultural products in the international arena.

\subsection{Play the "Visible Hand" of government actively}

\subsubsection{Increase capital investment, improve agricultural infrastructure}

As the basis of agricultural development, it is necessary for government departments to attach importance to the modernization of agricultural infrastructure construction, including the construction of rural transport, water conservancy facilities and centralized wholesale market. Only the convenience of transportation, the fruits of labor of farmers and enterprises can "go out" more and more: only irrigation facilities become more advance, and the drought disaster losses of farmers suffer can lead to a minimum: only the wholesale market improved, the exchange between agricultural products and circulation can become smoother. To implement the planning guide, the government first played the role of macro-control guide. Make a good development plan of modern agriculture, combined with the objectives, priorities and tasks of inherent requirement of the development of modern agriculture, and in strict accordance with the requirements of urban and rural development, to enhance the comprehensive agricultural production capacity furthermore, vigorously to improve the market competitiveness of agricultural products, comprehensively to implement the scientific development concept, and to achieve sustainable development of agriculture; to encourage the construction of service-oriented facilities and to ensure the quality of agricultural products, to provide good disease control and prevention for animal and plant, promote the industrialization of grain and animal husbandry and 
aquaculture, comprehensively enhance the comprehensive level of agriculture and competition force.

\subsubsection{The degree of agricultural mechanization upgrade perfect}

Compared with the agricultural labor situation of developed countries of Europe and the developed countries and the major agricultural exporters, we can easily find that the agricultural production mechanization of these countries is very high, so the labor productivity and the unit output rate are very high. By drawing lessons from the experience of these countries and encouraging industry to promote agricultural development so that the level of agricultural mechanization in China can be improved, the Government can use the way on the purchase of agricultural machinery from policy to carry out the policy of agricultural machinery to the countryside and expand the use of agricultural machinery. By increasing the level of agricultural mechanization, to achieve the modernization of agricultural production so that it will improve the international competitiveness of China's agricultural products.

\subsubsection{Integrate land resources, encourage operation at an appropriate scale}

According to the China's national conditions, it is a good way to accelerate the land transfer at a large scale and integrate the land-use, under the guidance of the Government, combined with the requirement of agricultural products quality from international market ,It is necessary to achieve moderate scale operation. Focus on the integration of land, achieve large-scale production, so that it is easily to achieve the industrialization of agricultural production and reduce costs, it is also necessary to promote new agricultural technologies and new varieties. Encourage and support a batch of leading enterprises with high production scale, rational management and strong profitability and taking into account the use and research of agricultural science and technology, to achieve re-allocation of resources, industrial nurturing agriculture, enterprise production, large-scale production, to go out with the overall packaging in a way of Strong combination, will play a good role in guiding the lead. In addition to create more jobs opportunity, accelerating surplus labor transfer the role they play are conducive to enhancing the international competitiveness of China's agricultural products.

\section{References}

1. G. E. Zhang, L. Q. Xu, B. Wu, Agricultural Modernization Research , 4, 449-452(2008).

2. E Jingping, The Conservation of China Soil and Water Conservation, 12, 7-9(2003).

3. G. Q. Li, Journal of Shandong Agricultural Administrators' College, 3, 43-45(2012).

4. H. L. Ma, Study on the International Competitiveness of Agricultural Products in Heilongjiang Province [D]. University of Harbin Commerce, 2013.

5. S. Lin, M. Chuan, G. Q. Cheng, J. L. Zhang, Journal of Management World, 1, 97-103, 153(2003).

6. J. Y. Chen, A. P. Yao, Business Times, 2, 49-51(2014).

7. S. H. Tang, Jianghan Forum, 5, 75-78(2011).

8. H. Y. Sun, International Business and Economics of Heilongjiang, 6, 7-9(2009).

9. J. Li, Business Economics, 9, 11-12(2010).

10. Y. D. Wang, J. Shang, Academic Exchange, 1, 107-111(2008). 